\title{
Comparison Between Conventional Design and Cathode Gas Recirculation Design of a Direct-Syngas Solid Oxide Fuel Cell- Gas Turbine Hybrid Systems Part I: Design Performance
}

\author{
Vahid Azami ${ }^{a, * *}$ and Mortaza Yari ${ }^{b}$ \\ a Department of Mechanical Engineering, Mohaghegh Ardabili University, Ardabil, Iran \\ ${ }^{b}$ Department of Mechanical Engineering, Tabriz University, Tabriz, Iran
}

\begin{abstract}
In this paper, a conventional SOFC-GT hybrid system and an SOFC-GT hybrid system with cathode gas recirculation system fuelled with syngas as the main source of energy were analyzed and their performances were compared. In the conventional SOFC-GT hybrid system the incoming air to the cathode is heated at the air recuperator and air preheater to meet the required cathode inlet temperature while in the SOFC-GT hybrid system with cathode gas recirculation, in addition to the air recuperator and air preheater, also the recirculation of the cathode exhaust gas is used to meet the required cathode inlet temperature. The system performances have been analyzed by means of models developed with the computer program Cycle-Tempo. A complete model of the SOFC-GT hybrid system with these two configurations evaluated in terms of energy and exergy efficiencies and their performance characteristics were compared. Simulation results show that the electrical energy and exergy efficiencies achieved in the cathode gas recirculation plant (64.76\% and $66.28 \%$, respectively) are significantly higher than those obtained in the conventional plant (54.53\% and $55.8 \%)$.
\end{abstract}

Keywords: Solid oxide fuel cell, Gas turbine, Cathode gas recirculation, Exergy.

Article History: Received Feb 23 ${ }^{\text {rd }}$ 2017; Received in revised form May 26 ${ }^{\text {th }}$ 2017; Accepted June 1 ${ }^{\text {st }} 2017$; Available online

How to Cite This Article: Azami, V, and Yari, M. (2017) Comparison between conventional design and cathode gas recirculation design of a direct-syngas solid oxide fuel cell-gas turbine hybrid systems part I: Design performance. International Journal of Renewable Energy Develeopment, 6(2), 127-136.

https://doi.org/10.14710/ijred.6.2.127-136

\section{Introduction}

One of the promising technologies for power generation is fuel cell. Within the fuel cell types, solid oxide fuel cell are being paid much attention because of their advantages like high efficiency and flexibility for different fuels, furthermore when operated at high pressures, they can be combined with gas turbines for obtaining very high efficiency for electricity generation. The hybrid system of solid oxide fuel cell combined with gas turbine (SOFC-GT) cycle has been identified to be a superior power generation technology compared to many other options. SiemensWestinghouse Power Corporation developed the first advanced power system, which integrates a SOFC stack with the gas turbine engines. The pressurize system with operating pressure $3 \mathrm{~atm}$ generates 220
$\mathrm{kW}$ of electrical power at a net electrical efficiency of $55 \%$ (Hirschenhofer et al. 2008).

In spite of the introduction of many innovative cycles for the SOFC-GT hybrid system, its universal configuration is not yet fully established. Studies to develop new system configurations for better performance are still in progress. In this regard, a number studies were analysed ambient pressure design of hybrid SOFC-GT system and performances were compared with a pressurized system, like the studies of Park et al. (2006; 2009). Kuchonthara et al. (2003) evaluated a combination of SOFC and various gas turbine cycles such as STIG cycle, gas turbine/steam turbine combined cycle and humid air turbine (HAT) cycle. In the STIG cycle, the generated steam is injected into a GT combustion chamber in

\footnotetext{
*Corresponding author: vazami@uma.ac.ir
} 
Citation: Azami, V and Yari, M. (2017), Comparison between conventional design and cathode gas recirculation design of a direct-syngas solid oxide fuel cell-gas turbine hybrid systems part I: Design performance. International Journal of Renewable Energy Development, 6(2),127-136, https://doi.org/10.14710/ijred.6.2.127-136

$\mathrm{P}$ a g e | 128

order to increase the GT power and the system efficiency.

In most published papers on the SOFC-GT hybrid system modeling in the open literature, methane or natural gas has been used to fuel the system. In comparison with other alternative fuel, syngas obtained from biomass gasification is a very attractive green fuel for use in solid oxide fuel cells. It has relatively high hydrogen content and can be produced renewably through the gasification process of biomass feed-stocks and thus, a promising alternative fuel for the SOFC-GT hybrid system. However, there are limited numerical studies that investigated utilization of non-conventional fuels. Therefore, in the proposed SOFC-GT hybrid system, syngas obtained from biomass gasification is used as the fuel.

The SOFC-GT hybrid system with anode and cathode exhaust gas recycling is an interesting power system that can minimize the required heat input for the system and maximize the system efficiency. In this regard, saebea et al. (2012) showed that the recirculation of anode exhaust gas can increase the system efficiency for an SOFC system integrated with an ethanol reformer process by reducing the heat input for the preheating steam used in the steam reformer. However, exergy based performance analysis is not considered for SOFC-GT hybrid systems with cathode gas recirculation and a study is required to investigate exergetic performance for such systems.

This paper presents the results from thermodynamic analysis of SOFC-GT hybrid system with cathode gas recirculation system (CRS) of power levels near 3.5 MW. Syngas obtained from biomass gasification is considered as a fuel for the present study. Thermodynamic calculations were first carried out to evaluate the performance of the conventional SOFC-GT hybrid system (CS), including thermodynamic properties of all major streams in the cycle and operational conditions of all main equipment. Then, the same analysis is presented for the SOFC-GT system with cathode gas recirculation and the results are compared with the results of the conventional SOFC-GT hybrid system.

\section{System configurations}

\subsection{Conventional SOFC unit}

The schematic diagram of a SOFC system without cathode gas recirculation is illustrated in Fig. 1. It consist of an air preheater, a fuel preheater, an anode recycle blower, a direct internal reformer solid oxide fuel cell (DIR-SOFC) and a combustor. The heated fuel in the fuel recuperator, is heated again in the fuel preheater (unit 6) by the combustor discharge stream. After that, the preheated fuel mixed with the recycled fuel from the anode exit before entering the DIRSOFC system where it is reformed and electrochemically reacted. Apparatus no. 8 in Fig. 1 represents DIR-SOFC device. The fuel stream temperature rises to $900 \circ \mathrm{C}$ at stream 6 before entering the anode side of SOFC. On the other side, the heated air in the air recuperator, is preheated in air preheater (unit 104) to $586 \circ \mathrm{C}$ by the GT discharge stream. These entering temperatures (anode and cathode inlet temperature) are essential requirements for proper functioning of SOFC stacks. Otherwise, the stacks will shut down automatically, which is due to low temperature of fuel and oxidant to initiate the chemical reactions (Rokni 2010).

In the fuel cell the fuel is converted into electricity. The operating temperature of the DIR-SOFC was assumed to be $950 \circ \mathrm{C}$. However, the outlet temperature was assumed to be $1000 \circ \mathrm{C}$. As shown in Fig. 1, a fraction of depleted anode gas recirculates to SOFC unit providing heat and steam for fuel reformation.

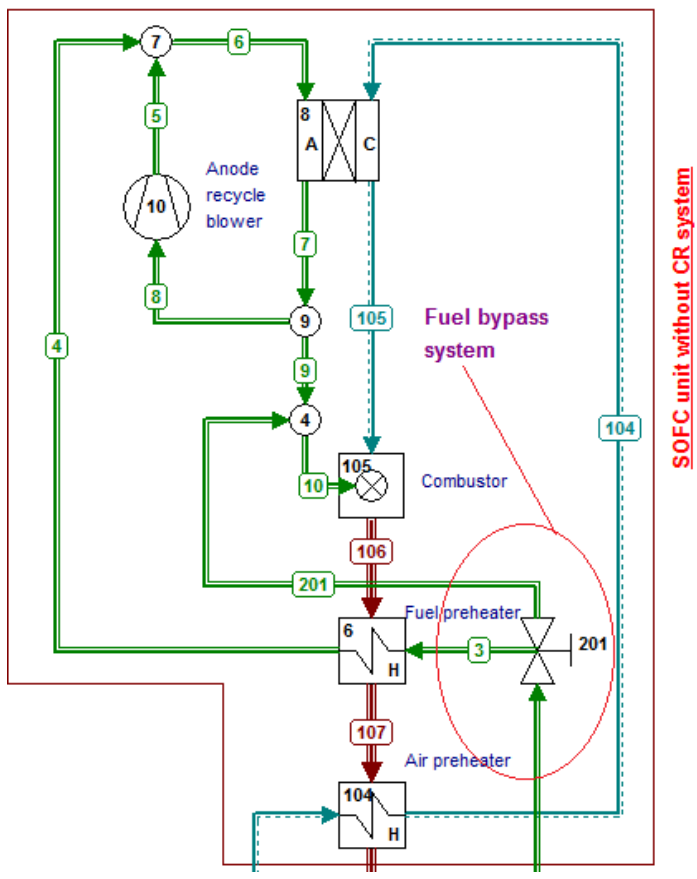

Fig. 1 Flow diagram of the conventional SOFC system

The remaining gas flows into the combustion zone, mixes with depleted air, and burns and produce heat for the air and fuel preheating. This system with some variations is conceptually similar to that used in the demonstration plant of Siemens Westinghouse as shown in Fig. 2. In the Siemens Westinghouse designed configuration, NG is used as a fuel and hence pre-reformer and indirect internal reformer is used for the fuel reformation. While, in our proposed configuration, SOFC is fueled with syngas which methane content is low, hence to simplify and also for better thermal integrating, direct internal reformer is used for fuel reformation. In the conventional SOFCGT hybrid system, the cathode recirculation flow is zero. Instead, all required heat for the heated fuel and air streams to the anode and cathode inlet 
temperature are provided by the combustor and gas turbine exhaust gas.

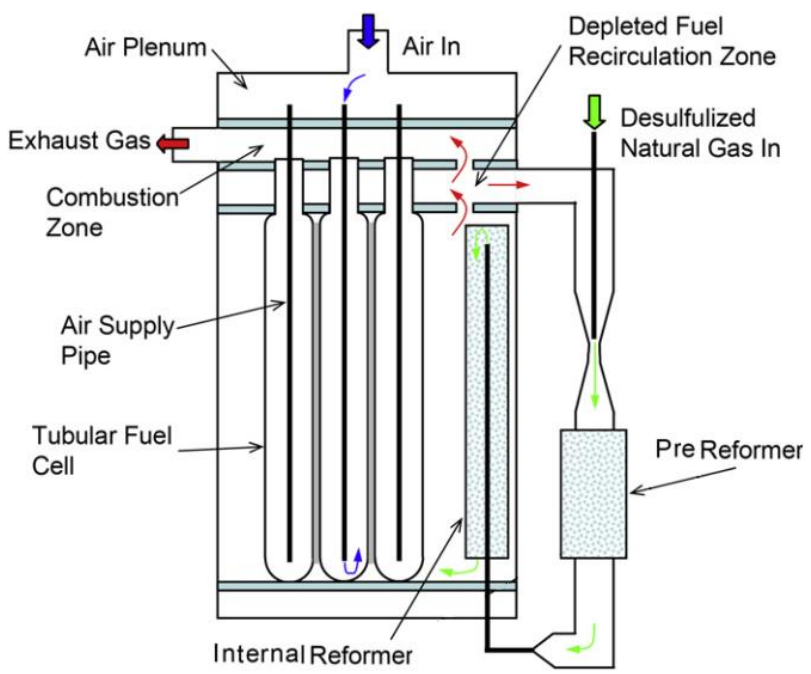

Fig. 2 Flow scheme of the tubular SOFC stack (McLarty et al. 2012)

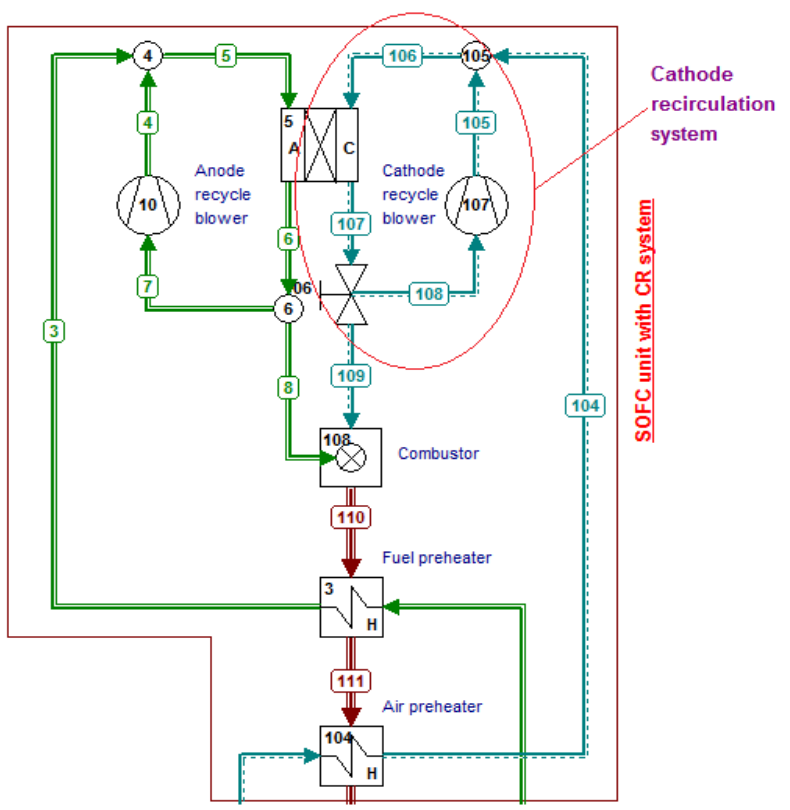

Fig. 3 Flow diagram of the SOFC system with cathode gas recirculation

\subsection{SOFC system with cathode gas recirculation}

The proposed SOFC system with cathode gas recirculation consist of, air and fuel preheater, anode and cathode recycle blower, a (DIR-SOFC) and a combustor as shown in Fig. 3. The major differences between two cycles are the option which employed for heating cathode inlet stream. In CR hybrid system the cathode inlet air after heated at the air recuperating and air preheating components is mixed with depleted air from the cathode air recycle before entering the cathode side of SOFC.

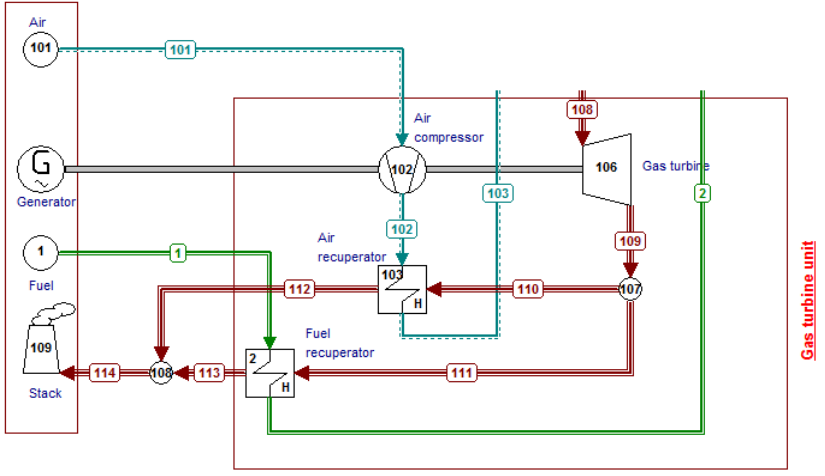

Fig. 4 Flow diagram of the GT system

\subsection{GT system}

The schematic diagram of a recuperative gas turbine is illustrated in Fig. 4. It consists of an air recuperatur, a fuel recuperatur, an air compressor, a fuel compressor and a generator. The air enters the system through the air compressor. Thereafter, the compressed air is preheated in the recuperator and then for reheating guided to the preheater. The depleted fuel and air from the SOFC stack are burned into the combustor and produce heat for the air and fuel reheating. After that, the exhaust gases are expanded in the turbine (unit 106) to supply the necessary power for the compressor and a generator.

\section{Model description}

The thermodynamic simulations of the system are performed by the Cycle-Tempo software (Cycle-Tempo software 2017). This software was developed by TU Delft (Delft University of Technology), as a modeling tool for the thermodynamic analysis and optimization of systems for the production of electricity, heat and refrigeration. Cycle-Tempo employs a Gibbs free energy minimization based routine for equilibrium calculations in the combustor model and in the fuel cell model. Some assumptions used in the simulations are:

- The systems are operated in steady state.

- The processes are adiabatic.

- Heat losses from system components to environment are negligible.

- The cathode and anode inlet temperature of the fuel cell are assumed to be equal.

- The temperature of the SOFC is homogeneous and midway between the inlet and exit temperatures.

The fuel used in the calculation is syngas obtained from biomass gasification (Ankur 2010) with moisture content of $10 \mathrm{wt} \%$; the dry composition of the biomass in given in Table 1. The DIR-SOFC fuel cell model available in Cycle-Tempo software is used to calculate the performance of the system. A SOFC-GT hybrid system consists of a SOFC, heat exchanger, mixer, and 
Citation: Azami, V and Yari, M. (2017), Comparison between conventional design and cathode gas recirculation design of a direct-syngas solid oxide fuel cell-gas turbine hybrid systems part I: Design performance. International Journal of Renewable Energy Development, 6(2),127-136, https://doi.org/10.14710/ijred.6.2.127-136

P a g e | 130

afterburner. Various types of design are available for solid oxide fuel cell. Direct internal reforming fuel cell is selected for the present study.

Table 1

Dry composition of the syngas used in the models (Ankur 2010)

\begin{tabular}{lll} 
Component & Unit & Value \\
\hline $\mathrm{CH}_{4}$ & $\mathrm{~mol} \%$ & 3 \\
$\mathrm{H}_{2}$ & $\mathrm{~mol} \%$ & 18 \\
$\mathrm{~N}_{2}$ & $\mathrm{~mol} \%$ & 50 \\
$\mathrm{CO}_{2}$ & $\mathrm{~mol} \%$ & 10 \\
$\mathrm{CO}$ & $\mathrm{mol} \%$ & 19 \\
$\mathrm{LHV}$ & $\mathrm{kJ} / \mathrm{kg}$ & 4939 \\
\hline
\end{tabular}

In the combustor a chemical reaction takes place between the fuel and oxidant. In order to determine the heat produced, it is therefore essential to calculate this composition. Under ideal conditions (residence time, mixture), the composition of the flue gas will be the same as the equilibrium composition corresponding to the composition of the reactants and the reaction conditions $\left(p_{\text {react }}, T_{\text {react }}\right)$.

The gas turbine operates with a typical recuperated Brayton cycle. It consists of a compressor, a recuperator, a burner, a turbine as well as a generator. In this paper, assume that it is possible to design turbines with the specific characteristics mentioned in this study (see Table 2). The power level given for the gas turbine generator determined the fuel mass flow gets into the system and hence fuel mass flow gets into the combustor. On the other hand, the cooling air required to keep the fuel cell at the required operating temperature determine the air mass flow rate gets into the system and hence air mass flow gets into the combustor. The description of the SOFC/GT hybrid system models is given in Refs. (Aravind 2009; Toonssen 2010; Cycle-tempo manuals 2017).

The energy equation of the heat exchanger can be used in two ways in the model calculation. The first option uses the energy equation to calculate an unknown mass flow ratio. In this option, first the enthalpies are determined. The enthalpies can be calculated when two state variables in the relevant pipe are known. In the second option the energy equation is used to calculate an unknown enthalpy. When a second state variable (e.g. the pressure) in the relevant pipe is known, the unknown temperature can be calculated. When the energy equation is used to calculate an unknown temperature, the mass flows ratio must be known from the energy equation. For the first iteration run an initial value is chosen for the mass flow ratio. For the following iteration runs the mass flows are used which are calculated in the previous iteration run. The unknown temperature is then known as a function of the enthalpy and another state property.

They are two ways to start the iteration in the program. One way is to specify the fuel mass flow ratio and the other way is to set the power output load of the fuel cell stack or GT gnerator. In this paper, mass flows through the system and hence the power level is set by the turbine power fixed at 1 MW. For the turbine-compressor combination drives a generator the energy output was calculated from Eq. (1).

$W_{\mathrm{G}}=\left[\left(W_{\mathrm{t}} \times \eta_{\mathrm{m}, \mathrm{t}}\right)-\left(-\frac{W_{\mathrm{c}}}{\eta_{\mathrm{m}, \mathrm{c}}}\right)\right] \times \eta_{\text {gen }}$

Where $W_{\mathrm{G}}$ is the power output of generator, $W_{\mathrm{t}}$ is the power output of turbine, $W_{\mathrm{c}}$ is the power consumption of the compressor $\eta_{\mathrm{m}, \mathrm{t}}$ is the mechanical efficiency of the turbine, $\eta_{\mathrm{m}, \mathrm{c}}$ is the mechanical efficiency of compressor and $\eta_{\mathrm{G}}$ is the efficiency of the generator. The desired inlet temperature of the turbine can be manipulated by the addition of fuel to the combustor or recirculation cathode exhaust air to the fuel cell. Two parameters are specified for the consideration of the added fuel or air recirculation to adjust the turbine inlet temperature, as follows:

$$
\begin{aligned}
& F B R=\frac{\Phi_{201}}{\Phi_{2}} \\
& A R R=\frac{\Phi_{108}}{\Phi_{107}}
\end{aligned}
$$

Where FBR is the fuel bypass ratio, $\Phi_{201}$ is the mass flow of the fuel that bypassed to the combustor, $\Phi_{2}$ is the mass flow of the fuel output from the fuel recuperator, ARR is the air recirculation ratio, $\Phi_{108}$ is the cathode outlet mass flow rate and $\Phi_{107}$ is mass flow rate of the cathode exhaust recirculation.

In the calculation of system efficiencies four steps can be distinguished:

$>$ Determination of the total energy input

$>$ Determination of the total energy production

$>$ Determination of the total own energy consumption

$>$ Calculation of system efficiencies

The heating value is defined as the energy that must be discharged when heating 1 kilogramme of fuel, when the fuel, oxidant and flue gas are all supplied or discharged at a pressure of $1 \mathrm{~atm}$ and a temperature of $25{ }^{\circ} \mathrm{C}$. In gaseous fuels, it is assumed for the higher heating value (HHV) that the water generated by the heating reactions (i.e. not the water that is already present in the gas or in the air) fully condenses. At the lower heating value (LHV), this water is fully present as vapour in the flue gas. The energy efficiencies are calculated based on the LHV of the fuel. Total energy input to the system is:

$E n_{\text {fuel }}=L H V_{\text {syngas fuel }} \times \Phi_{\text {syngas fuel }}$

$\Phi_{\text {syngas fuel }}$ is the mass flow of the syngas fuel fed to the system $\left(\mathrm{kgs}^{-1}\right)$ and $L H V_{\text {syngas fuel }}$ is the low heating value of the syngas $\left(\mathrm{kJkg}^{-1}\right)$. For the energy 
consumption the electricity driven compressors (not turbine driven compressors) are considered:

$$
A P C=-\frac{W_{\mathrm{c}}}{\eta_{\text {drive }}}
$$

$A P C$ is the auxiliary power consumption and $W_{\mathrm{c}}$ is the power absorbed by medium for a compressors which is not turbine driven. The efficiency of the compressor drive $\eta_{\text {drive }}$ is built up by two efficiencies: the mechanical efficiency $\eta_{\mathrm{m}}$ and the electric efficiency $\eta_{\mathrm{e}}$. The total efficiency is then determined as follows:

$\eta_{\text {drive }}=\eta_{\mathrm{e}} \times \eta_{\mathrm{m}}$

The energy efficiencies are calculated based on the LHV of the fuel. The Gross thermal efficiency, described by Eq. (7), is the ratio of the total produced electricity divided by the mass of the fuel input to the system times the lower heating value. Net thermal efficiency, described by Eq. (8), is defined as the value of the net produced electricity divided by the total fuel heating value. $P_{\mathrm{a}}$ is the total power consumption of auxiliary components including fuel compressors and air and fuel blowers $(\mathrm{kW})$.

$$
\begin{aligned}
& \eta_{\text {en,gross }}=-\frac{P_{\mathrm{el}}}{E n_{\mathrm{fuel}}} \\
& \eta_{\text {en,net }}=-\frac{P_{\mathrm{el}}-P_{\mathrm{a}}}{E n_{\mathrm{fuel}}}
\end{aligned}
$$

Besides system calculations, Cycle-Tempo can perform exergy calculations, the results of which form the basis for an exergy analysis of the system under consideration. For such an exergy analysis, it is important to have available exergy values of process flows and exergy losses in apparatuses, as well as exergy efficiencies of apparatuses. The gross and net electrical exergetic efficiency are calculated using the following equation:

$$
\begin{gathered}
\eta_{\text {ex,gross }}=-\frac{P_{\mathrm{el}}}{E x_{\text {fuel }}} \\
\eta_{\text {ex,net }}=-\frac{P_{\mathrm{el}}-P_{\mathrm{a}}}{E x_{\text {fuel }}}
\end{gathered}
$$

Table 2 summarizes the assumptions for the developed model of hybrid plant. The anode recycle stream is about $60 \mathrm{wt} \%$ of the anode-off gas stream. The operating temperature of the SOFC stacks and outlet temperatures were assumed to be $1000 \circ \mathrm{C}$. The cell resistance was assumed to be $5 \times 10^{-5} \mathrm{ohmm}^{2}$, and fuel utilization factor of SOFC was assumed to be $80 \%$. Since this study intends to perform a design analysis, the current density of the unit cell is assumed to be constant for all cases. Therefore, different powers obtained from the analysis can be realized by different cell stack size (e.g., cell active area). In design calculations, cell voltage, current density and fuel utilization factor are specified as an input parameter. On the basis of this data, the program calculates the corresponding cell resistance and cell active area. The mean current density was assumed to be $2500 \mathrm{Am}^{-2}$, and fuel utilization factor of SOFC was assumed to be $85 \%$. The efficiency of the DC/AC converter was assumed to be $97 \%$. The pressure drops at the all devices were assumed to be 0.02 bar.

Table 2

Assumptions for the SOFC-GT model at design point

$\begin{array}{lll}\text { Component } & \text { Unit } & \text { Value } \\ \text { Current density } & \mathrm{A} \mathrm{m}-2 & 2500 \\ \text { Equivalent fuel cell resistance } & \Omega \mathrm{m} 2 & 5 \mathrm{e}-5 \\ \text { Fuel utilization factor } & \% & 85 \\ \text { Cathode inlet temperature } & { }^{\circ} \mathrm{C} & 900 \\ \text { Anode inlet temperature } & { }^{\circ} & 900 \\ \text { Operating temperature in the SOFC, Tcell } & { }^{\circ} & 950 \\ \text { Operating pressure in the SOFC, Pcell } & \text { bar } & 3 \\ \text { DIR-SOFC exhaust gas temperature } & \circ \mathrm{C} & 1000 \\ \text { DIR-SOFC } \Delta \mathrm{P} \text { air/fuel side } & \mathrm{bar} & 0.02 \\ \text { Anode recirculation ratio } & \% & 60 \\ \text { Combustor } \Delta \mathrm{P} & \mathrm{bar} & 0.02 \\ \text { Fuel and air recuperator hot inlet-cold } & { }^{\circ} \mathrm{C} & 50 \\ \text { outlet temperature difference } & \mathrm{bar} & 0.02 \\ \text { Recuperator } \Delta \mathrm{P} \text { air/gas side } & \circ \mathrm{C} & 850 \\ \text { Turbine inlet temperature } & \% & 85 \\ \text { Turbine isentropic efficiency } & \% & 80 \\ \text { Compressor isentropic efficiency } & \% & 97 \\ \text { Turbine mechanical efficiency } & \% & 97 \\ \text { Compressor mechanical efficiency } & \% & 75 \\ \text { Isentropic efficiency for fuel compressor } & \% \\ \text { and blowers } & & \\ \text { Mechanical efficiency for fuel compressor } & \% & 95 \\ \text { and blowers } & \% & 97 \\ \text { DC/AC conversion efficiency } & \% & 94 \\ \text { Generator efficiency } & & \end{array}$

\section{Results}

\subsection{Conventional SOFC-GT hybrid system}

The main calculated parameters and the performance of the conventional SOFC-GT hybrid system with regard to energy and exergy conversion are listed in Tables 3 and 4. For the considered system fuel with the flow rate of $0.954 \mathrm{~kg} / \mathrm{s}$ enters the cycle at $25 \circ \mathrm{C}$ and 1.013 bar. The corresponding energy input to the system, $4357 \mathrm{~kW}$, is based on the lower heating value of the fuel. However, the corresponding exergy input to the system is $4258 \mathrm{~kW}$.

The fuel input to the system is pressurized at the fuel compressor to 3.05 bar. The power required for this compression is about $150 \mathrm{~kW}$. Then, the fuel is heated in fuel recuperator by the gas turbine discharge stream. The recovered heat in the fuel recuperator is $711 \mathrm{~kW}$. This heat is used to increase the temperature of fuel from $66{ }^{\circ} \mathrm{C}$ after the compressor to $586{ }^{\circ} \mathrm{C}$. After fuel recuperator, some portion of the fuel (About 0.309 of the stream 2 in Fig. 1) is bypassed to the combustor 
Citation: Azami, V and Yari, M. (2017), Comparison between conventional design and cathode gas recirculation design of a direct-syngas solid oxide fuel cell-gas turbine hybrid systems part I: Design performance. International Journal of Renewable Energy Development, 6(2),127-136, https://doi.org/10.14710/ijred.6.2.127-136

$\mathrm{P}$ a g e | 132

to meet the required fuel cell and turbine inlet temperature.

Furthermore, the fuel stream temperature needs to be increased to the inlet temperature of the SOFC. Therefore, it is further reheated to $713 \circ \mathrm{C}$ in fuel preheater by the exhaust of the combustor. The transmitted heat of fuel preheater is $125 \mathrm{~kW}$. After that, the preheated fuel mixed with the recycled fuel from the anode exit before entering the SOFC anode inlet. The mass flow rate of the SOFC anode inlet stream is $1.921 \mathrm{~kg} / \mathrm{s}$, and its temperature is $900 \circ \mathrm{C}$. The mass flow rate of the anode exhaust recirculation is $1.261 \mathrm{~kg} / \mathrm{s}$, and its temperature is equal to the outlet temperature of the SOFC, $1000 \circ \mathrm{C}$. The inlet air enters the system with the mass flow rate of $8.077 \mathrm{~kg} / \mathrm{s}$. The air pressure is increased to 3.05 bar at the air compressor by consuming $1158 \mathrm{~kW}$ power. Then, the air is heated in recuperator by the GT discharge stream. The recovered heat in the recuperator is 3667 $\mathrm{kW}$. This heat is used to increase the temperature of air from $162{ }^{\circ} \mathrm{C}$ after the compressor to $586{ }^{\circ} \mathrm{C}$. Furthermore, the air stream temperature needs to be increased to the operating temperature of the SOFC. Therefore, it is further reheated to $900 \circ \mathrm{C}$ in air preheater by the exhaust of the combustor. The transmitted heat of air preheater is $2913 \mathrm{~kW}$. The air stream is then fed to the SOFC cathode inlet.

Table 3

Key parameters data for the conventional SOFC-GT hybrid system

\begin{tabular}{lll}
\hline Component & Unit & Value \\
& & \\
\hline Fuel flow-rate to the system & $\mathrm{kg} / \mathrm{s}$ & 0.954 \\
Air flow-rate to the system & $\mathrm{kg} / \mathrm{s}$ & 8.077 \\
Recovered heat at the fuel recuperator & $\mathrm{kW}$ & 711 \\
Recovered heat at the air recuperator & $\mathrm{kW}$ & 3667 \\
Bypassed fuel fraction to the combustor & - & 0.309 \\
Fuel flow-rate to the combustor & $\mathrm{Kg} / \mathrm{s}$ & 1.136 \\
Combustor outlet temperature & $\circ \mathrm{C}$ & 1124 \\
Combustor outlet mass flow rate & $\mathrm{Kg} / \mathrm{s}$ & 9.032 \\
Exchanged heat at the fuel preheater & $\mathrm{kW}$ & 125 \\
Exchanged heat at the air preheater & $\mathrm{kW}$ & 2913 \\
Anode inlet flow ratio & $\mathrm{kg} / \mathrm{s}$ & 1.921 \\
Anode recirculation flow ratio & $\mathrm{kg} / \mathrm{s}$ & 1.261 \\
Anode outlet flow ratio & $\mathrm{kg} / \mathrm{s}$ & 2.102 \\
Cathode inlet flow ratio & $\mathrm{kg} / \mathrm{s}$ & 8.077 \\
Cathode outlet flow ratio & $\mathrm{kg} / \mathrm{s}$ & 7.896 \\
Stack exhaust gas temperature & $\circ \mathrm{C}$ & 199 \\
\hline
\end{tabular}

In the SOFC unit, electrochemical reaction takes place, and as a consequence, $1530 \mathrm{~kW}$ AC power is generated. The AC efficiency of power generation in the SOFC unit is $50.83 \%$. In the cathode side of the SOFC, because of the electrochemical reaction in the fuel cell the mass flow rate of air reduces from 8.077 to $7.896 \mathrm{~kg} / \mathrm{s}$. While in the anode side, because of the electrochemical reaction and formation of $\mathrm{H} 2 \mathrm{O}$, the mass flow rate of the anode increases from $1.921 \mathrm{~kg} / \mathrm{s}$ to $2.102 \mathrm{~kg} / \mathrm{s}$.
Tabel 4

Conventional SOFC-GT hybrid system energy and exergy performance

\begin{tabular}{lll} 
Parameters & Unit & Value \\
\hline Energy in fuel input to the system & $\mathrm{kW}$ & 4357 \\
Exergy in fuel input to the system & $\mathrm{kW}$ & 4258 \\
SOFC DC power output & $\mathrm{kW}$ & 1578 \\
SOFC AC power output & $\mathrm{kW}$ & 1530 \\
SOFC AC efficiency & $\%$ & 50.83 \\
Gas turbine generator power output & $\mathrm{kW}$ & 1000 \\
Gas turbine generator efficiency & $\%$ & 35.98 \\
Auxiliary power consumption & $\mathrm{kW}$ & 155 \\
Net power output & $\mathrm{kW}$ & 2376 \\
Net energy efficiency & $\%$ & 54.53 \\
Net exergy efficiency & $\%$ & 55.8 \\
\hline
\end{tabular}

The anode off-gas still contains some combustible components, which are combusted in a combustor using the depleted air coming from the fuel cell. The mass flow rate of the combustor outlet is $9.032 \mathrm{~kg} / \mathrm{s}$, and its temperature is $1124{ }^{\circ} \mathrm{C}$. The combustor exhaust is used to increase the fuel and air temperature respectively at fuel and air preheaters, before being fed to the GT. The flue gases stream temperature fall to $1113 \circ \mathrm{C}$ and $850 \circ \mathrm{C}$ at fuel and air preheater hot outlets streams, respectively. The hot flue gasses leaving the air preheater with a temperature of $850 \circ \mathrm{C}$ are expanded in the turbine of the GT, which is connected through a shaft with the compressor and a generator. The output power generated in the turbine is $2221 \mathrm{~kW}$, and delivered power in the generator after adjusting for air compressor power consumption is $1000 \mathrm{~kW}$. The efficiency of power generation in the GT unit is 35.98 $\%$. The flow exits the GT at a temperature of $636 \circ \mathrm{C}$ and pressure of 1.033 bar. This stream preheats the air and fuel stream separately at fuel and air recuperators, and its temperature reduces to $116 \circ \mathrm{C}$ and $213 \circ \mathrm{C}$ at streams 112 and 113, respectively. Finally the exhaust gas is discharged to the atmosphere at a temperature of $199 \circ \mathrm{C}$. In this system, delivered gross power is $2530 \mathrm{~kW}$ and delivered net power after adjusting for auxiliary power consumption is $2376 \mathrm{~kW}$. The net hybrid system efficiency achieved is $54.53 \%$

\subsection{SOFC-GT system with cathode gas recirculation}

The main calculated parameters and the performance of the SOFC-GT hybrid system with cathode gas recirculation with regard to energy and exergy conversion are listed in Tables 5 and 6. Syngas with the flow rate of $1.207 \mathrm{~kg} / \mathrm{s}$, enters the cycle at 25 ${ }^{\circ} \mathrm{C}$ and 1.013 bar. The corresponding energy and exergy input to the system is, $5510 \mathrm{~kW}$ and $5384 \mathrm{~kW}$, respectively, are based on the lower heating value of the fuel. The fuel input to the system is pressurized at the fuel compressor to 3.05 bar and $66{ }^{\circ} \mathrm{C}$ at stream 2 . The fuel compressor consumes $190 \mathrm{~kW}$. The temperature of stream 2 increases to $588{ }^{\circ} \mathrm{C}$ by $902 \mathrm{~kW}$ heat transfer at fuel recuoerator. 
Furthermore, the fuel stream temperature needs to be increased to the inlet temperature of the SOFC. Therefore, it is further reheated to $713 \circ \mathrm{C}$ in fuel preheater by the exhaust of the combustor. The transmitted heat of fuel preheater is $225 \mathrm{~kW}$. The streams 3 and 4 are then mixed to form stream 5 with a high concentration of steam required by the reforming and water-gas shift reactions (see Fig. 3). The mass flow rate of the SOFC anode inlet stream is $3.515 \mathrm{~kg} / \mathrm{s}$, and its temperature is $900 \circ \mathrm{C}$. The mass flow rate of the anode exhaust recirculation is 2.308 $\mathrm{kg} / \mathrm{s}$, and its temperature is equal to the outlet temperature of the SOFC, $1000 \circ \mathrm{C}$. In the anode recycle a fuel blower is used to overcome the pressure drop in the fuel cell. The fuel blower in the anode recycle consumes $8 \mathrm{~kW}$ of power.

Tabel 5

Key parameters data for the SOFC-GT hybrid system with cathode gas recirculation

\begin{tabular}{lcc}
\hline Component & Unit & Value \\
& & \\
\hline Fuel flow-rate to the system & $\mathrm{kg} / \mathrm{s}$ & 1.207 \\
Air flow-rate to the system & $\mathrm{kg} / \mathrm{s}$ & 7.444 \\
Recovered heat at the fuel recuperator & $\mathrm{kW}$ & 902 \\
Recovered heat at the air recuperator & $\mathrm{kW}$ & 3395 \\
Cathode exhaust gas recirculation ratio & - & 0.51 \\
Fuel flow-rate to the combustor & $\mathrm{Kg} / \mathrm{s}$ & 1.539 \\
Combustor outlet temperature & $\circ \mathrm{C}$ & 1036 \\
Combustor outlet mass flow rate & $\mathrm{Kg} / \mathrm{s}$ & 8.651 \\
Exchanged heat at the fuel preheater & $\mathrm{kW}$ & 225 \\
Exchanged heat at the air preheater & $\mathrm{kW}$ & 1767 \\
Anode inlet flow ratio & $\mathrm{kg} / \mathrm{s}$ & 3.515 \\
Anode recirculation flow ratio & $\mathrm{kg} / \mathrm{s}$ & 2.308 \\
Anode outlet flow ratio & $\mathrm{kg} / \mathrm{s}$ & 3.847 \\
Cathode inlet flow ratio & $\mathrm{kg} / \mathrm{s}$ & 14.838 \\
Cathode recirculation flow ratio & $\mathrm{kg} / \mathrm{s}$ & 7.394 \\
Cathode outlet flow ratio & $\mathrm{kg} / \mathrm{s}$ & 14.506 \\
Stack exhaust gas temperature & $\circ \mathrm{C}$ & 194 \\
\hline
\end{tabular}

\section{Tabel 6}

Energy and exergy performance of the SOFC-GT hybrid system with cathode gas recirculation

\begin{tabular}{lll}
\hline Component & Unit & Value \\
& & \\
\hline Energy in fuel input to the system & $\mathrm{kW}$ & 5510 \\
Exergy in fuel input to the system & $\mathrm{kW}$ & 5384 \\
SOFC DC power output & $\mathrm{kW}$ & 2878 \\
SOFC AC power output & $\mathrm{kW}$ & 2792 \\
SOFC AC efficiency & $\%$ & 50.67 \\
Gas turbine generator power output & $\mathrm{kW}$ & 1000 \\
Gas turbine generator efficiency & $\%$ & 37.99 \\
Auxiliary power consumption & $\mathrm{kW}$ & 223 \\
Net power output & $\mathrm{kW}$ & 3569 \\
Net energy efficiency & $\%$ & 64.76 \\
Net exergy efficiency & $\%$ & 66.28 \\
\hline
\end{tabular}

On the other hand, the inlet air enters the system at $25 \circ \mathrm{C}$ and 1.013 bar with the mass flow rate of 7.444 $\mathrm{kg} / \mathrm{h}$. The air pressure is increased to 3.05 bar at the air compressor by consuming $1067 \mathrm{~kW}$ of power. The air stream temperature is further increased in air recuperator and air preheater by the GT discharge stream and the combustor exhaust stream, respectively, and its temperature rises to $588 \circ \mathrm{C}$ and $796 \circ \mathrm{C}$ at streams 103 and 104, respectively. The heat duties of air recuperator and air preheater are 3395 and $1767 \mathrm{~kW}$, respectively. The hot compressed air is then mixed with depleted air from the cathode air recycle. This cathode air recycle stream is about 51 wt\% of the stream leaving the cathode of the fuel cell. The air stream is then fed to the SOFC at the cathode inlet.

The electrochemical reactions in the SOFC generate $2792 \mathrm{~kW}$ AC power. The AC efficiency of power generation in the SOFC is $50.67 \%$ (based on LHV). Because of the electrochemical reaction in the anodeside of SOFC and formation of water, the mass flow rate of the anode increases to $3.847 \mathrm{~kg} / \mathrm{s}$. The SOFC anode exhaust is then divided into two streams: one is recycled to the anode side of fuel cell and the other is fed to the combustor. In the meantime, due to oxygen companies in the air flow in the SOFC reactions, the molar flow rate of the air reduces from 14.838 to $14.506 \mathrm{~kg} / \mathrm{s}$. The SOFC cathode exhaust is then divided into two streams: one is recycled to the cathode side of SOFC and the other is fed to the combustor, where it mixes with the anode exhaust stream. This mixture is combusted in the combustor, so the temperature of combustion products increases to $1036 \circ \mathrm{C}$. The mass flow rate of the combustor exhaust is $8.651 \mathrm{~kg} / \mathrm{s}$. The combustor exhaust is used to increase fuel and air temperature to $713 \circ \mathrm{C}$ and $796 \circ \mathrm{C}$ at fuel and air preheater, respectively before being fed to the GT. The TIT is fixed at the $850 \circ \mathrm{C}$ by adjusting the cathode exhaust recirculation ratio. The hot flue gasses leaving the air preheater with a temperature of $850 \circ \mathrm{C}$ are expanded in the turbine of the GT unit, which is connected through a shaft with the compressor and a generator. The output power generated in the turbine is $2131 \mathrm{~kW}$, and delivered power in the generator after adjusting for air compressor power consumption is $1000 \mathrm{~kW}$. The efficiency of power generation in the GT unit is 37.99 $\%$. The combustion products leave the GT at a temperature of $638 \circ \mathrm{C}$ and pressure of 1.033 bar. This stream heats the fuel at fuel recuperator and the air at air recuperator. Eventually the exhaust is discharged to the atmosphere at a temperature of $194 \circ \mathrm{C}$. Energy and exergy available at the stack are considered to be the losses to the environment. In this system, delivered gross power is $3792 \mathrm{~kW}$ and delivered net power after adjusting for auxiliary power consumption is $3569 \mathrm{~kW}$. The net hybrid system efficiency achieved is $64.76 \%$.

\subsection{Comparison of the both systems}

As Fig. 5 show, due to cathode recirculation the air mass flow rate to the system in the configuration with cathode recirculation is slightly lower than that in the conventional configuration $(7.44 \mathrm{~kg} / \mathrm{s}$ vs. $8.077 \mathrm{~kg} / \mathrm{s}$, respectively). While, comparison of the SOFC cathode inlet air mass flow in Fig. 5 shows that the cathode inlet air mass flow of the SOFC in the configuration 
Citation: Azami, V and Yari, M. (2017), Comparison between conventional design and cathode gas recirculation design of a direct-syngas solid oxide fuel cell-gas turbine hybrid systems part I: Design performance. International Journal of Renewable Energy Development, 6(2),127-136, https://doi.org/10.14710/ijred.6.2.127-136

$\mathrm{P}$ a g e | 134

with cathode recirculation is significantly higher than that in the configuration without cathode recirculation (14.838 kW vs. $8.077 \mathrm{~kg} / \mathrm{s}$, respectively). The reason is when the fuel recuperator exhaust is partially bypassed to the combustor, in order to adjust the turbine, anode and cathode inlet temperature, before entering the SOFC, the mass flow rate of the anode inlet reduces from $3.515 \mathrm{~kg} / \mathrm{s}$ in the cycle with cathode recirculation to $1.921 \mathrm{~kg} / \mathrm{s}$ in the cycle without cathode recirculation. This means lower cooling air required to keep the fuel cell at the required operating temperature in the conventional configuration.

The comparison of energy input to the system for two configurations (see Fig. 6) shows that the energy input to the system is higher in the configuration with cathode recirculation $(5510 \mathrm{~kW}$ vs. $4357 \mathrm{~kW}$, respectively). The reason is when the SOFC cathode exhaust is partially recycled before entering the combustor, the air mass flow rate of the combustor reduces from $7.896 \mathrm{~kg} / \mathrm{s}$ in the cycle without cathode recirculation to $7.112 \mathrm{~kg} / \mathrm{s}$ in the cycle with cathode recirculation. As low air is entered to the combustor, and there is no variation in the turbine inlet temperature and pressure ratio and since the generator produces is fixed, the mass flow through the turbine decreases. This causes higher fuel input to the system and hence the energy input to the system increases, as shown in Fig. 6. The exergy input of both systems has a similar changing trend as energy input (5384 kW vs. $4258 \mathrm{~kW}$, respectively).

As Fig. 7 show, due to higher air mass flow rate to the system and hence higher mass flow through the turbine and since the generator produces is fixed, air compressor power consumption and hence gas turbine power production in the conventional configuration is slightly higher than that in the configuration with cathode recirculation (1158 and $2221 \mathrm{~kW}$ vs. 1067 and $2131 \mathrm{~kW}$, respectively).

On the other hand, due to higher fuel mass flow rate to the system and hence higher mass flow through the fuel compressor, fuel compressor power consumption in the configuration with cathode gas recirculation is higher than that in the conventional configuration, as shown in Fig. 8. (190 kW vs. $150 \mathrm{~kW}$, respectively).

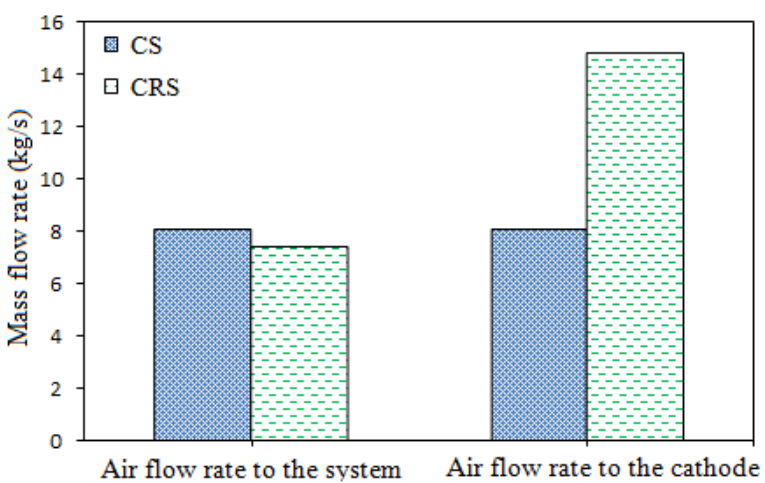

Fig. 5 Comparison of the air flow to the system and cathode inlet air flow for two configurations

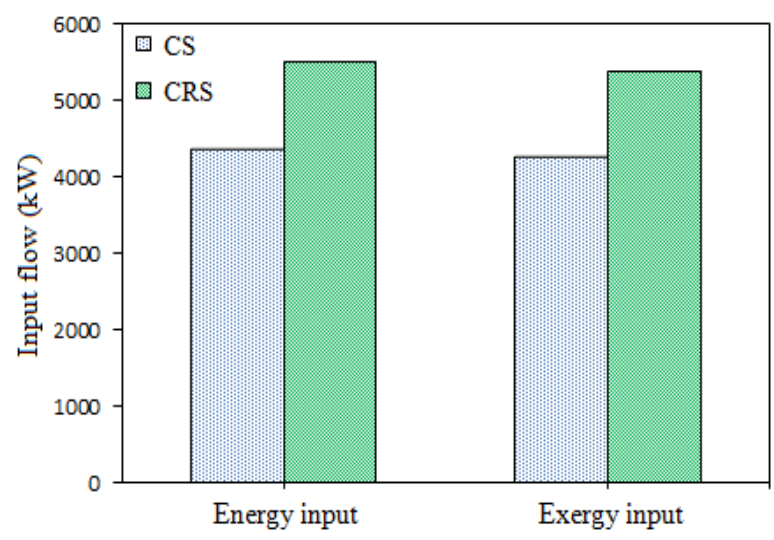

Fig. 6 Comparison of the energy and exergy input to the system for two configurations

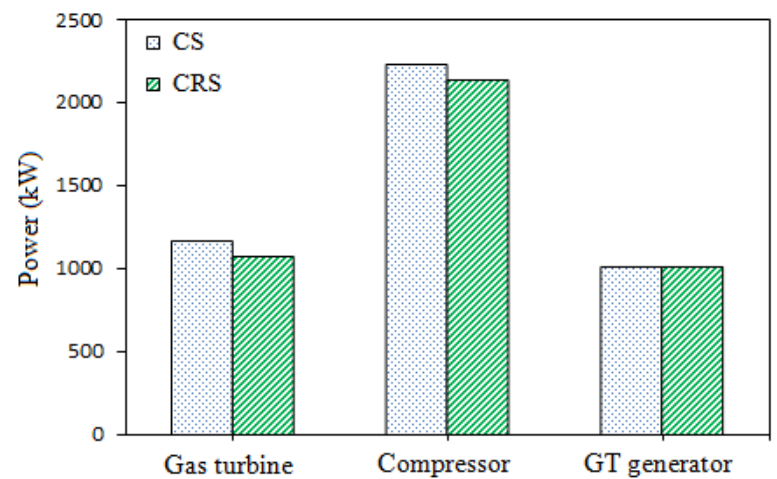

Fig. 7 Comparison power of main components of the gas turbine unit for two configurations

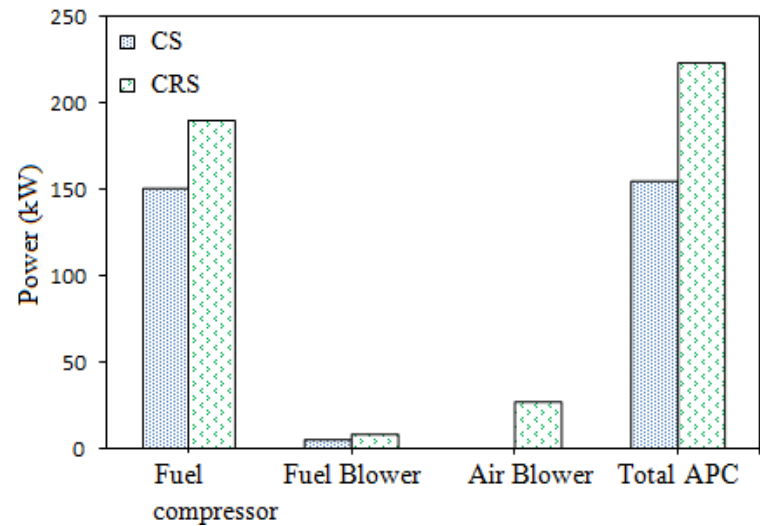

Fig. 8 Comparison power consumption of the auxiliary units for two configurations

In the cycle without cathode recirculation, the cathode recirculation flow rate is zero and that is why in Fig. 8 air blower power consumption is removed. In addition, due to higher power consumption of the fuel compressor and air blower consumption, the total auxiliary power consumption of the hybrid system in the configuration with cathode recirculation is $223 \mathrm{~kW}$, which is higher than in the total auxiliary power consumption of the configuration without cathode recirculation at $155 \mathrm{~kW}$.

Comparison of the SOFC AC output power in Fig. 9 shows that the output power of the SOFC in the configuration without cathode recirculation is 
significantly lower than that in the configuration with cathode recirculation $(1530 \mathrm{~kW}$ vs. $2792 \mathrm{~kW}$, respectively). The reason is when the fuel recuperator exhaust is partially bypassed to the combustor (about $31 \mathrm{wt} \%$ of the stream leaving the cold side of the fuel recuperator) before entering the fuel preheater, the fuel mass flow rate of the SOFC anode inlet reduces from $3.515 \mathrm{~kg} / \mathrm{s}$ in the cycle without cathode recirculation to $1.921 \mathrm{~kg} / \mathrm{s}$ in the cycle with cathode recirculation. Therefore, there is less power generated in the SOFC of the conventional configuration.

On the other hand, due to higher SOFC power output of the configuration with cathode recirculation and since the generator power produce of both cycle without and with cathode recirculation is equal to $1000 \mathrm{~kW}$, gross output power of the SOFC-GT hybrid system in the configuration with cathode recirculation is significantly higher than that in the configuration without cathode recirculation $(3792 \mathrm{~kW}$ vs. $2530 \mathrm{~kW}$, respectively) as shown in Fig. 9. This is also the reason for the higher net output power of the SOFC-GT hybrid system in the cycle with cathode recirculation in comparison to the cycle without cathode recirculation (3569 kW vs. $2376 \mathrm{~kW}$, respectively), despite the higher total auxiliary power consumption (see Figs. 8 ). In addition, due to higher gross and net output power, the gross and net energy efficiency of the hybrid system in the configuration with cathode gas recirculation are 68.82 and $64.76 \%$, respectively, which is significantly higher than that in the configuration without cathode gas recirculation at 58.07 and $54.53 \%$, respectively (see Figs. 10 ). The gross and net exergy efficiency of both systems has a similar changing trend as energy input (70.43 and $66.28 \%$ vs. 59.43 and $55.8 \%$, respectively).

Fig. 11 and 12 illustrates the exergy loss and destruction balance for two configurations. Apparatuses included in each unit are given in Table 7. It is observed that, in both systems, there is a large amount of exergy loss to the environment; about $25 \%$ or $467 \mathrm{~kW}$ of the total exergy input in the conventional configuration and about $26 \%$ or $484 \mathrm{~kW}$ of the total exergy input in the configuration with cathode recirculation. This high quality energy can be used further for useful energy production such as a bottoming cycle, space heating or cooling etc. The exergy available at the exhaust gas is considered as a loss here. As Figs. 11 and 12 shows, due to higher fuel mass flow rate through the fuel cell and hence higher electrochemical reactions, the exergy destruction in the fuel cell (FC) in the configuration with cathode recirculation is significantly higher than that in the fuel cell in the conventional configuration (13\% or 231 $\mathrm{kW}$ vs. $7 \%$ or $127 \mathrm{~kW}$, respectively). However, the exergy destruction of the combustion chamber (CC) in the configuration without cathode recirculation, due to the bypassed additional fuel into the $\mathrm{CC}$, is significantly higher than that in the configuration with cathode recirculation ( $18 \%$ or $347 \mathrm{~kW}$ vs. $11 \%$ or 194 $\mathrm{kW}$, respectively).

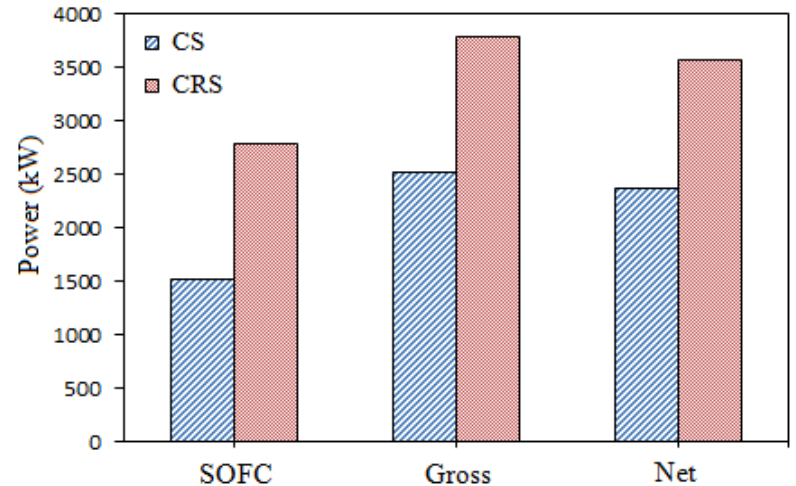

Fig. 9 Comparison power of main components of the hybrid system for two configurations

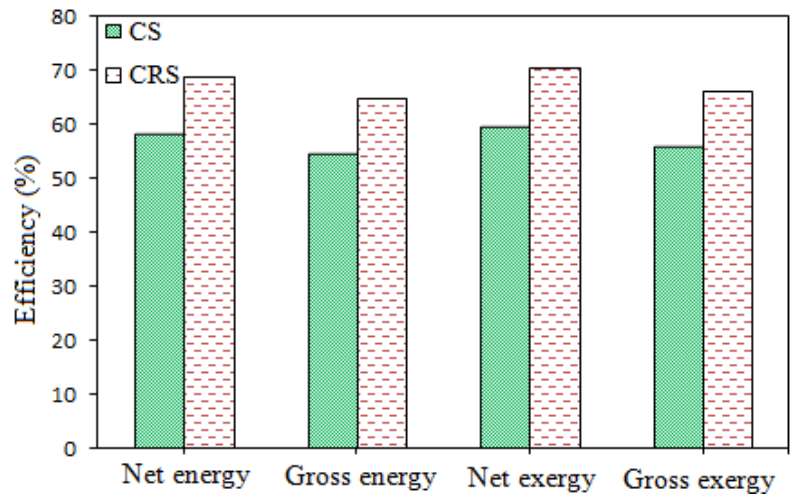

Fig. 10 Comparison performance of the hybrid system for two configurations

Table 7

Apparatuses included in each unit

\begin{tabular}{lll}
\hline Unit & $\begin{array}{l}\text { CS (see Figs. 1 } \\
\text { and 4) }\end{array}$ & $\begin{array}{l}\text { CRS (see Figs. 3 } \\
\text { and 4) }\end{array}$ \\
\hline $\begin{array}{l}\text { Fuel heating } \\
\text { system (FHS) }\end{array}$ & $2,6 \& 7$ & $2,3 \& 4$ \\
$\begin{array}{l}\text { Air heating system } \\
\text { (AHS) }\end{array}$ & $103 \& 104$ & $103,104 \& 105$ \\
$\begin{array}{l}\text { Fuel cell (FC) } \\
\text { Combustion } \\
\text { chamber (CC) }\end{array}$ & 8 & 5 \\
$\begin{array}{l}\text { Gas turbine (GT) } \\
\text { Air compressor } \\
\text { (AC) }\end{array}$ & 105 & 108 \\
Stack & 102 & 106 \\
Other & 109 & 102 \\
& $108,4 \&$ & 109 \\
\hline
\end{tabular}

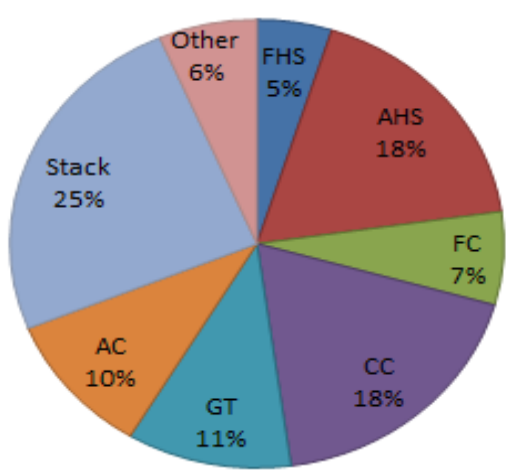

Fig. 11 Exergy destruction of the conventional configuration in percentage of total exergy destructed 
Citation: Azami, V and Yari, M. (2017), Comparison between conventional design and cathode gas recirculation design of a direct-syngas solid oxide fuel cell-gas turbine hybrid systems part I: Design performance. International Journal of Renewable Energy Development, 6(2),127-136, https://doi.org/10.14710/ijred.6.2.127-136

$\mathrm{P}$ a g e | 136

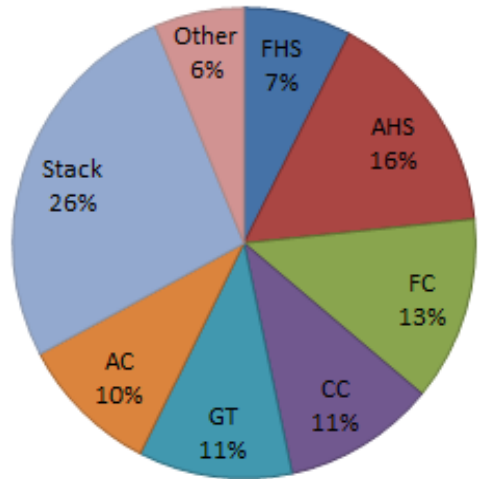

Fig. 12 Exergy destruction of the configuration without cathode recirculation in percentage of total exergy destructed

\section{Conclusion}

In this paper the SOFC-GT hybrid system fuelled by syngas from biomass gasification was evaluated by thermodynamic calculations. Two alternative options were proposed to provided, required heat for the heated fuel and air streams to the anode and cathode inlet temperature.

Although the generator power produce of both cycle with and without cathode recirculation were equal to $1000 \mathrm{~kW}$, the SOFC power output of the cycle with cathode recirculation was much higher than that in the cycle without cathode recirculation, which means higher efficiency for the same generator power produce. Also, the gross and net output power of the system in the cycle with cathode recirculation was higher, whereas, the total auxiliary power consumption of the hybrid system was higher in the cycle with cathode recirculation.

The comparison of the system performance indicated that gross energy and exergy efficiency of the SOFC-GT hybrid system with cathode gas recirculation was 68.82 and $70.43 \%$, respectively, which was much higher than that in the cycle without cathode recirculation at 58.07 and $59.43 \%$, respectively, whereas, the energy and exergy input to the system was higher in the cycle with cathode exhaust gas recirculation. Also, despite the high total auxiliary power consumption, the net energy and exergy efficiency in the cycle with cathode recirculation was higher (64.76 and $66.28 \%$ vs. 54.53 and $55.8 \%$, respectively).

\section{References}

Ankur scientific energy technologies pvt. ltd, http://www.ankurscientific.com/range.htm; 2010.

Aravind, P.V., Woudstra, T., Woudstra, N. \& Spliethoff, H. (2009) Thermodynamic evaluation of small scale systems with biomass gasifiers, solid oxide fuel cells with Ni/GDC anodes and gas turbines. J Power Sources, 190(2), 461-75.

Delft University of Technology. (2017) Cycle-tempo software (Release 5.0), http://www.asimptote.nl/software/cycle-tempo.

Delft University of Technology. (2017) Cycle-tempo manuals http://www.asimptote.nl/assets/media/7d155f62-ffe $2-4 \mathrm{a} 9 \mathrm{e}$ 9f33-bb003c80bd2b.pdf

Hirschenhofer, J.H., Stauler, D.B., Engleman, R.R. \& Klett, M.G. (1998) Fuel cell handbook. 4th ed. Parsons Corporation Reading P.A. for U.S. Department of Energy.

Kuchonthara, P., Bhattacharya, S. \& Tsutsumi, A. (2003) Combinations of solid oxide fuel cell and several enhanced gas turbine cycles. Journal of Power Sources, 124, 65-75.

McLarty, D., Kuniba, Y., Brouwer, J., Samuelsen, S. (2012) Experimental and theoretical evidence for control requirements in solid oxide fuel cell gas turbine hybrid systems. J Power Sources, 209, 195-203.

Park, S.K. \& Kim, T.S. (2006) Comparison between pressurized design and ambient pressure design of hybrid solid oxide fuel cell gas-turbine systems. J Power Sources, 158, 225-44

Park, S.K., Kim, T.S., Sohn, J.L. \& Mech, J. (2009) Influence of steam injection through exhaust heat recovery on the design performance of solid oxide fuel cell - gas turbine hybrid systems. J Mech Sci Technol, 23,550-8.

Saebea, D., Patcharavochot, Y. \& Arpornwichanop, A. (2012) Analysis of an ethanolfuelled solid oxide fuel cell system using partial anode exhaust gas recirculation. J Power Sources, 208, 120-30.

Rokni, M. (2010) Plant characteristics of an integrated solid oxide fuel cell cycle and a steam cycle. Energy 2010;35:46919.

Rokni, M. (2010) Thermodynamic analysis of an integrated solid oxide fuel cell cycle with a rankine cycle. Energy Conversion and Management, 51,2724-32

Toonssen, R., Aravind, P.V., Smit, G., Woudstra, N. \& Verkooijen, A.H.M. (2010) System study on hydrothermal gasification combined with a hybrid solid oxide fuel cell gas turbine. Fuel Cells, doi:10.1002/fuce.2009001

Website:

https://www.siemens.com/global/en/home.html 